\title{
Sections 3 and 4 of the Human Rights Act and their impact on the United Kingdom's constitutional arrangements
}

\author{
Ayesha Riaz*
}

\begin{abstract}
In the late 1990s, the Human Rights Act 1998 (HRA) was incorporated into British law. Section 3 of the HRA grants British judges to go as far as they can when interpreting domestic legislation in line with the European Convention on Human Rights. This article reviews relevant case law to assert that despite this extension of judicial power, British judges interpret domestic legislation in line with its fundamental purpose when reviewing whether it is compliant with the European Convention on Human Rights. This article also considers the impact of section 4 of the HRA on the UK's constitutional arrangements. Section 4 allows judges to issue a 'declaration of incompatibility' upon finding domestic legislation to be incompatible with the European Convention on Human Rights. Although section 4 has empowered senior British judges to issue declarations of incompatibility, Parliament must still decide whether those declarations can invalidate domestic law. This reality has sparked a debate about bi-polar sovereignty between the Parliament and the judiciary. Despite this clear tension between the Parliament and the judiciary, this article contends that parliamentary sovereignty has not been eradicated due to sections 3 and 4 of the HRA.
\end{abstract}

\section{Introduction}

While the introduction of the Human Rights Act 1998 (HRA) into British law has granted judges more discretion, it has also blurred the boundary between the executive, legislature and the judiciary. This article seeks to address the 'so-called' increasing tension between the HRA and parliamentary sovereignty. The debate is centred on whether unelected judges or elected politicians should be the final adjudicators in a rights-based democracy. This issue sits at the centre of academic discussion and some commentators argue that the rights enshrined in the European Convention on Human Rights (ECHR) carry a higher status than statute. ${ }^{1}$ Therefore 'only an independent judiciary, immune from executive domination and above faction can construe' these rights. ${ }^{2}$

\footnotetext{
* PhD candidate at QMUL; senior lecturer at the University of Greenwich; part-time teacher at LSE.

${ }^{1}$ Danny Nicol, 'Are Convention Rights a no-go Zone for Parliament?'(2002) Public Law 438.

2 ibid.
} 
Section 3(1) of the HRA gives rise to a new interpretative duty to the judiciary which enables it to decide whether domestic legislation is compatible with the ECHR. The section states that 'so far as it is possible to do so, primary legislation and subordinate legislation must be read and given effect in a way which is compatible with Convention rights'. ${ }^{3}$ The words 'so far as it is possible' serve as a base on which this controversy lies regarding the impact of the HRA on the legislature, executive and the judiciary, ${ }^{4}$ Where it is not possible to invoke section 3(1), the courts can use section 4 the HRA to issue a 'declaration of incompatibility'. 5 Parliament must amend the domestic legislation to ensure that it complies with the ECHR under section 4 of the HRA. However, the defective piece of domestic legislation will continue to apply until Parliament thinks it is necessary to rectify the defect.

Section 3 of the HRA states:

(1) So far as it is possible to do so, primary legislation and subordinate legislation must be read and given effect in a way which is compatible with the Convention rights.

Section 4 of the HRA states:

(1) Subsection (2) applies in any proceedings in which a court determines whether a provision of primary legislation is compatible with a Convention right.

(2) If the court is satisfied that the provision is incompatible with a Convention right, it may make a declaration of that incompatibility.

(3) Subsection (4) applies in any proceedings in which a court determines whether a provision of subordinate legislation, made in the exercise of a power conferred by primary legislation, is compatible with a Convention right.

(4) If the court is satisfied-

(a)that the provision is incompatible with a Convention right, and

(b)that (disregarding any possibility of revocation) the primary legislation concerned prevents removal of the incompatibility,

\footnotetext{
${ }^{3}$ Human Rights Act (HRA), s 3.

${ }^{4}$ ibid.

${ }^{5}$ HRA, s 4
} 
it may make a declaration of that incompatibility.

The main objective of the HRA is to ensure that the executive, legislature and the judiciary each play a role by engaging in a trialogue about the nature of human rights and how they should be applied. ${ }^{6}$ Similarly, declarations of incompatibility under section 4 of the HRA act as the main driving force behind these inter-institutional dialogues between the executive, legislature and the judiciary, ${ }^{7}$ An interpretation under section 3 acts as a signal to Parliament that the statute in question is incompatible with the ECHR. ${ }^{8}$ However, by reading words into that statute (in line with its fundamental purpose), the judiciary can construe the law in a manner that is compatible with Convention rights. ${ }^{9}$ Although section 3 grants the judiciary some flexibility, according to the jurisprudence cited in this article, it is clear that the courts are using this flexibility appropriately and are not swaying away from the fundamental purpose of the statute. While this interpretative flexibility is a victory for legal constitutionalists, political constitutionalists, on the other hand, have not been pleased. ${ }^{10}$

There is no fixed definition of legal and political constitutionalism. ${ }^{11}$ According to Kavanagh, political constitutionalism embodies 'a general pro-Parliament/anti-court outlook on public issues', ${ }^{12}$ whereas legal constitutionalism embodies 'a more supportive orientation towards judicial power'. ${ }^{13}$ Legal constitutionalists will be excited about this change because according to them, sovereignty should be shared between Parliament, executive and judiciary. ${ }^{14}$ However, for political constitutionalists, this concept of having 'shared' or 'bi-polar' sovereignty is exceedingly problematic. According to them, judges lack the democratic mandate to be accountable to the electorate. ${ }^{15}$ Clearly, section 3 (1) grants judges more leeway,

\footnotetext{
${ }^{6}$ Francesca Klug, 'A Bill of Rights: Do We Need One or Do We Already Have One' (2007) Public Law 701, 709; See Christopher Crawford, 'Dialogue and Rights Compatible Interpretations under Section 3 of the Human Rights Act 1998' (2014) 25:1 Kings Law Journal 34, 35.

${ }^{7}$ Julie Debeljak, 'The British Perspective on Bill of Rights: The Human Rights Act 1998 UK'(2002 Bill of Rights Conference, Sydney, 21 June 2002).

${ }^{8}$ Sandra Fredman 'Bringing Rights Home' (1998) 114 Law Quarterly Review 538, 538-9.

${ }^{9}$ Alison L. Young, Parliamentary Sovereignty and the Human Rights Act (Hart Publishing 2009) 10.

${ }^{10}$ Note that there is no fixed definition of legal and political constitutionalism. According to Kavanagh, political constitutionalism embodies 'a general pro-Parliament/anti-court outlook on public issues', whereas legal constitutionalism embodies 'a more supportive orientation towards judicial power.' See, Alexander Latham Gambi, 'Political Constitutionalism and Legal Constitutionalism-an Imaginary Opposition' (2020) 40:4 Oxford Journal of Legal Studies 737, 738; Aileen Kavanagh, 'Recasting the Political Constitution: From Rivals to Relationships' (2019) 30 KLJ 43.

${ }^{11}$ Alexander Latham Gambi, Political Constitutionalism and Legal Constitutionalism-an Imaginary Opposition (2020) 40 (4) Oxford Journal of Legal Studies 737,738.

${ }^{12}$ Aileen Kavanagh, Recasting the Political Constitution: From Rivals to Relationships (2019) 30 KLJ 43.

${ }^{13}$ ibid.

14 ibid.

15 ibid.
} 
as they are not accountable to the electorate for their decisions and are able to think 'more freely'.

Tension between the executive and judiciary can be healthy as they enable the judiciary to hold the executive to account for their actions, albeit partially. ${ }^{16}$ Indeed, Hogg and Bushell noted that the discourse in relation to the British constitution has increased between the judiciary, legislature and the executive as a result of the HRA. ${ }^{17}$ Now judges can engage in a constructive debate about 'rights' ${ }^{18}$ However, critics argument that the judiciary is now 'interfering' with the inner workings of the executive and the legislature is incorrect. ${ }^{19}$

This article proceeds in the following manner-Part 2 explains the background of the HRA and contends that the Labour Party introduced the HRA to allow domestic courts to adjudicate human rights matters. Part 3 considers appropriate case-law and considers how section 3 has empowered the judiciary. Nevertheless, this article argues that judges use section 3 to make the statute Convention-compliant. Part 4 explains the importance of declarations of incompatibility and argues that they maintain the supremacy of Parliament as 'declarations do not affect the validity, continuing operation or enforcement of the provision' ${ }^{20}$ Part 5 considers the reviews of the HRA. One of the aims of the latest review initiated in December 2020 was to consider whether the judiciary was adjudicating on areas of policy. ${ }^{21}$ This article argues that judges refrain from adjudicating on areas of policy under section 3.

\section{Background to the Act}

The United Kingdom (UK) has been bound by the ECHR since $1953 .{ }^{22}$ Domestic courts were unable to enforce ECHR rights until the implementation of the HRA in $1998 .{ }^{23}$ Prior its implementation, an aggrieved citizen would have to bear the expenditure of taking his/her case

\footnotetext{
${ }^{16}$ Andrew Le Sueur, Maurice Sunkin, Jo Murkens, Public Law Text, Cases and Materials ( $3^{\text {rd }}$ edition, Oxford University Press 2016) 22-3.

${ }^{17}$ Peter Hogg and Alison Bushell, 'The Charter Dialogue Between Courts and Legislatures' (1997) 35 Osgoode Hall Law Journal 75.

${ }^{18}$ Francesca Klug, 'The Human Rights Act; A “third way” or a "third wave” of Bill of Rights' (2001) 4 European Human Rights Law Review 361, 370.

${ }^{19}$ Andrew Le Sueur, Maurice Sunkin, Jo Murkens, Public Law Text, Cases and Materials ( $3^{\text {rd }}$ edition, Oxford University Press 2016), 22-3.

${ }^{20}$ HRA, s 4(2)(a).

${ }^{21}$ Ministry of Justice, 'Independent Human Rights Act Review', < $\underline{\text { www.gov.uk/guidance/independent-human- }}$ rights-act-review\#contents $>$ accessed 29 December 2020. Note that It is anticipated that the Review will run until the Summer of 2021.

${ }^{22}$ Le Sueur \& et al [n 19] 200.

23 ibid.
} 
to the European Court of Human Rights (hereafter ECtHR) ${ }^{24}$ Following the introduction of the HRA, 'Convention Rights' were incorporated into domestic law. ${ }^{25}$

The Labour Party's manifesto commitment included the enactment of the HRA as it believed that the British courts would benefit from the rulings of the ECtHR in reaching similar decisions. ${ }^{26}$ When the Labour Party won the General Elections of 1997, they published a White Paper explaining the proposals contained in the HRA. ${ }^{27}$ It was also believed that there would be closer scrutiny of human rights implications on new legislation and policies when Convention rights are adjudicated upon by British courts. ${ }^{28}$ This would mean that if primary legislation was incompatible with the ECHR, then a decision by domestic courts to that effect would be much more effective than a ruling from the ECtHR. ${ }^{29}$ Accordingly, the HRA was brought fully into force on 2 October $2000 .^{30}$

Legal constitutionalists welcomed the adoption of the HRA in the UK. Nevertheless, critics and political constitutionalists maintain that, to an extent, the HRA has undermined the UK's parliamentary sovereignty. ${ }^{31}$ For example, Professor Bradley states the combination of the new interpretative duty under section 3 with the possibility of issuing a 'declaration of incompatibility' under section 4 , 'takes the courts into the examination of questions that, apart from the HRA, would have been regarded as political questions' ${ }^{32}$ Professor Moravcsik stated that the UK would not be minded to grant unprecedented powers to a domestic court, let alone an international court. ${ }^{33}$ This is contrary to the principle that Parliament is commissioned to enact law, and judges are supposed to interpret those laws. ${ }^{34}$

\footnotetext{
${ }^{24}$ Anthony Lester, 'Human Rights and the British Constitution' in Jeffrey Jowell and Dawn Oliver (eds), The Changing Constitution ( $7^{\text {th }}$ edition, OUP 2011) 74.

25 ibid.

${ }^{26}$ Labour Party, 'New Labour Because Britain Deserves Better' (Manifesto of the Labour Party for the General Election of 1997, Labour Party 1997) < www.labour-party.org.uk/manifestos/1997/1997-labourmanifesto.shtml> accessed 4 March 2021; Le Sueur \& et al [n 22] 214.

${ }^{27}$ Home Office, Rights Brought Home: The Human Rights Bill (White Paper, Cm 3782, 1997 Le Sueur \& et al [n 19] 214.

${ }^{28}$ Labour Campaign for Human Rights, 'What is the Human Rights

Act?'<https://www.lchr.org.uk/humanrightsact background $>$ accessed 28 December 2020.

${ }^{29}$ Le Sueur \& et al [n 19] 215-16.

${ }^{30}$ Le Sueur \& et al [n 19] 214.

${ }^{31}$ Andrew Moravcsik, 'The Origins of Human Rights Regimes: Democratic Delegation in Postwar Europe' (2000) 54:2 International Organization 217.

${ }^{32}$ Anthony Bradley, 'Paper to the House of Lords Constitution Committee: Relations Between the Executive, the Judiciary and Parliament'(Sixth Report, Session 2006-2007, Appendix 4) para 27.

${ }^{33}$ Moravcsik [n 31].

34 ibid.
} 


\section{Section 3 of the HRA -Giving power to the judges}

As stated previously, section 3(1) of the HRA explicitly states that all legislation must be read and given effect in a way which is compatible with Convention rights 'in so far as possible'. ${ }^{35}$ The result is that judges must determine the meaning of the legislation. ${ }^{36}$ Although this grants considerable leeway to judges, this article argues that British judges adopt a restrictive approach when interpreting the statute in line with its fundamental purpose in light of the ECHR.

As per section 3 the judiciary is tasked with interpreting and not legislating. ${ }^{37}$ From the case-law, it is apparent that the judges interpret domestic legislation with reference to its nature and contents when figuring out the 'legal meaning'. ${ }^{38}$ Judges consider the context in which the words were used when interpreting the meaning of the statute. ${ }^{39}$ When explaining the legal meaning of a term, the judge must provide a reasoned analysis for his/her conclusion. ${ }^{40}$ The ECHR has been framed using general words that require interpretation of terms. Thus, judicial interpretation involves a degree of creativity and forms an important element of judicial lawmaking. Of course, judges are unwilling to cross the line between interpretation and legislation, and case law demonstrates that despite the hazy nature of the ECHR, judges interpret domestic legislation in line with its fundamental purpose to make it Convention-compliant. This article argues that when judges make the statute Convention-compliant, they refrain from radically altering the effect of the legislation. ${ }^{41}$

The HRA also empowers the British courts to quash delegated legislation on Convention grounds, which is a remarkable expansion of judicial power in the UK. ${ }^{42}$ In this regard, the HRA has expanded the remit of judicial review as it empowers judges to examine contentious questions that traditionally fell within the jurisdiction of the legislature. This has slightly increased the tension between the judiciary and legislative branches of the state. Indeed, the former Home Secretary Charles Clarke stated that the HRA has 'shifted the balance

\footnotetext{
35 HRA, s 3.

${ }^{36}$ Le Sueur \& et al [n 19] 218.

${ }^{37}$ Richard Blakeley, 'Counting Sheep: Ghaidan v Godin-Mendoza and the True Extent of Section 3 of the Human Rights Act' (2005) 1 Cambridge Student Law Review 1, 2.

${ }^{38}$ Johan Steyn, 'Dynamic Interpretation Amidst an Orgy of Statutes' (2004) 3 EHRLR 245, 256.

${ }^{39}$ Blakeley [n 37] 2.

40 ibid.

${ }^{41}$ Poplar Housing and Regeneration Community Association Ltd v Donoghue [2001] EWCA Civ 595

42 Bradley [n 32] para 27.
} 
of powers towards the judiciary'. ${ }^{43}$ This article will expand on this power shift in part 4 when analysing terrorism legislation.

Nevertheless, some may argue that judges are merely undertaking their duty as required by section 3 (the duty to interpret statutes in a manner compatible with Convention rights) and section 6 (the duty to safeguard Convention rights) of the HRA. ${ }^{44}$ Thus, if Parliament passes legislation that contravenes the ECHR, judges, who act as guardians of the rule of law, ${ }^{45}$ are empowered by virtue of section 3 to refuse to apply the statute.

\subsection{The unrestricted operation of section 3 and its relationship with section 4}

Section 3 requires primary, subordinate or delegated legislation to 'be read and given effect in a way which is compatible with Convention rights', but only 'so far as it is possible to do so' ${ }^{46}$ Thus, it appears that the legislation will continue to apply even if it is not possible for the court to make it convention-compliant. ${ }^{47}$ The problem for political constitutionalists lies within the word 'possible' and the extent to which judicial activism is permitted when deciding whether legislation is Convention-compliant.

Case law may help answer this question. In $R v$ Secretary of State for the Home Department, ex parte Simms, Lord Hoffman stated that the HRA does not set aside the fundamental principle of parliamentary sovereignty. ${ }^{48} \mathrm{He}$ said that as the UK lacks a codified constitution, 'the constraints upon the exercise of Parliament are ultimately political, not legal' rules. ${ }^{49}$ This means that the HRA merely reinforces existing rights under the constitution where Parliament remains the supreme body. However, some may argue that judges are better placed to rectify matters where legislatures fail.

\footnotetext{
${ }^{43}$ House of Lord's Constitution Committee, Relations between the Executive, the Judiciary and Parliament, Sixth Report, Session 2006-07, chapter 2 at para 32.

${ }^{44}$ Human Rights Act 1998, ss.3 and 6.

${ }^{45}$ The rule of law embodies four principles-that the government and private actors remain accountable under the law; the laws are clear, publicised, stable and protect basic rights of citizens; that the processes by which laws are enacted, administered and enforced are accessible and fair and finally that justice is delivered timely by judges who are honest, competent, ethical and neutral. See World Justice Project, 'What is the Rule of Law' $<$ https://worldjusticeproject.org/about-us/overview/what-rule-law $>$ accessed 28 December 2020.

${ }^{46}$ HRA, s 3.

${ }^{47}$ HRA, s $3(2)$.

${ }^{48}$ [1999] UKHL 33, para 33.

49 ibid.
} 
Alternatively, in $R v D P P$, ex parte Kebeline and Others, ${ }^{50}$ Lord Hope explained that judges should adopt a more generous approach when dealing with fundamental rights. The case concerned Algerian nationals who were charged under The Prevention of Terrorism (Temporary Provisions) Act 1989 by the DPP but were awaiting trial. The issue was whether provisions within this Act contravened Article 6 of the ECHR. ${ }^{51}$ Lord Hope affirmed that section 3 of the HRA strongly influences how judges interpret statutes.

Additionally, Lord Steyn, in $R v A$, stated that the courts should use section $3 .^{52}$ But, where this is not possible, then as a last resort, the courts can make use of section 4 to issue a 'declaration of incompatibility'. In this case, the defendant was charged with rape. The judge at first instance held that the complainant could not be cross-examined, and that evidence could not be relied on about her alleged sexual relationship with the defendant. On appeal to the House of Lords, Lord Steyn found that section 41 of the Youth Justice and Criminal Evidence Act 1991 contravened the defendant's right to a fair trial under Article 6 of the ECHR. By adopting a wider interpretation of section 3, Lord Steyn was able to find a solution which ensured that 'section 41 will have achieved a major part of its objective', but without its 'excessive reach as reflected in section 3 of the 1998 Act'. ${ }^{53}$ Indeed, Lord Steyn even commented that courts can utilise section 3 where they feel they are 'linguistically strained', as evidently, he did. ${ }^{54}$. Although section 3 has empowered British judges, it is clear that they are not deviating from the thrust of the statute and the ECHR to ensure that they reach a fair and balanced decision in the circumstances.

If judges are capable of abiding by the 'thrust' of the legislation then they can utilise section 3 to their advantage. ${ }^{55}$ In the seminal case of Ghaidan v Godin-Mendoza, ${ }^{56}$ the House of Lords (now the Supreme Court) adopted a purposive approach to interpretation. The samesex partner had lived in a stable and close relationship for many years. The issue in this case was whether a person in a homosexual relationship could inherit a statutory tenancy under the Rent Act 1977. In accordance with paragraph 2(1) of Schedule 1 of the Rent Act, the surviving spouse of the tenant (in a heterosexual relationship) could be granted the right of succession.

\footnotetext{
${ }^{50}$ [2000] 2 A.C. 326.

51 Right to a Fair Trial.

52 (No 2) [2001] UKHL 25.

53 ibid para 45.

${ }^{54}$ ibid para 44.

${ }^{55} \operatorname{Re} \mathrm{S}$ [2003] EWCA CIV 963.

56 [2004] UKHL 30.
} 
By 1988, the meaning of 'surviving spouse' included a person who was residing with the original tenant as his/her wife or husband. The main question was whether this interpretation could cover same-sex partners as the Rent Act did not cover homosexual partners?

The House of Lords held that it would be acting in contravention of Article 14 (prohibition from discrimination), and Article 8 (right to respect for private and family life) of the ECHR to deny the respondent the right to succeed under a statutory tenancy. However, this begged the controversial question of whether the judges could read words into the Rent Act to make it Convention-compliant? The judges applied the ordinary meaning of the Rent Act and the words 'as his or her wife of husband' in the Act were read 'as if they were his or her wife or husband' to comply with Articles 8 and 14 of the ECHR to protect the security of tenure enjoyed by a person in a homosexual relationship. The majority held that the Rent Act was Convention-compliant, apart from Lord Millet. However, prior to the HRA, in Fitzpatrick v Sterling House Association, ${ }^{57}$ a case with similar facts to Ghaidan, the House of Lords held that a homosexual couple could not be successful under the provision of the Rent Act.

This article will now review the main judgments in Ghaidan as they provide an insight into sections 3 and 4. Lord Nicolls noted that section 3 is of crucial significance given that it transfers the UK's responsibilities under the ECHR into its domestic system. ${ }^{58} \mathrm{He}$ stated that section 3 is ambiguous and the difficulty lies with the term 'possible'. ${ }^{59}$ However, he stated that Parliament has already assumed a suitable alternative to section 3 which is exercised by judges when they issue a 'declaration of incompatibility' under section $4 .{ }^{60} \mathrm{He}$ also stated that judges are tasked with ascertaining the intention that Parliament attributed to the Rent Act. ${ }^{61}$ According to Lord Nicolls, there was no difficulty in this case as paragraph 2 of schedule 1 of the Rent Act of 1977 could extend to same-sex couples. ${ }^{62}$

The Lord Chancellor (a member of the executive, legislature and the judiciary at that time) stated that there will not be any need to issue judicial declarations of incompatibility due to the intended impact of section $3 .{ }^{63}$ When interpreting legislation in accordance with section 3 , courts should construe legislation in line with its fundamental purpose thereby preserving

\footnotetext{
${ }^{57}$ [2001] 1 AC 27.

58 [2001] 1 AC 27, para 26.

59 [2004] UKHL 30 para 27.

60 ibid 27.

${ }^{61}$ ibid 35 .

62 [2004] UKHL 30 para 35.

${ }^{63}$ Hansard, HL, col. 849 (5 February 1998).
} 
the constitutional boundary between interpretation and legislation. ${ }^{64}$ Judges usurp the function of Parliament once they start to legislate. This judgment illustrates that section 3 can be applied restrictively or expansively, and at times a court may be able to read words into the statute as long as the court can abide by the thrust of the legislation to make it Convention-compliant. ${ }^{65}$

Lord Steyn went a step further and affirmed the use of section 3. In his judgment, he stated that judges should only utilise section 4 of the HRA and issue a 'declaration of incompatibility' where it was not possible to make the legislation Convention-compliant. ${ }^{66}$ Lord Steyn quoted $R$ (Anderson) $v$ Secretary of State for the Home Department, ${ }^{67}$ where it was stated that the Home Secretary was not the appropriate person to decide the length of the tariff imposed on prisoners under Article 6 (right to a fair trial) of the ECHR ${ }^{68} \mathrm{He}$ also cited Bellinger $v$ Bellinger ${ }^{69}$ where it was held that Parliament alone retains the competence of extending the meaning of the term 'gender'. ${ }^{70}$ Thus, declarations of incompatibility were issued in both cases. ${ }^{71}$ However, Lord Steyn admitted that section 4 should be used as a last resort, because through it judges question the inner workings of Parliamentarians and indirectly inform them that the Act of Parliament was subordinate to the ECHR. ${ }^{72}$ Lord Steyn recognised that the HRA was passed to 'bring rights home' which can be achieved by virtue of the interpretive duty under section 3 as opposed to section $4 .{ }^{73}$

Lord Millet, on the other hand, stated that section 3 merely enables judges to 'interpret' legislation and adds nothing more than this. ${ }^{74}$ He said that judges cannot supply words and alter the meaning of the legislation. ${ }^{75}$ This, he added, would be usurping the role of Parliament and rewriting legislation. ${ }^{76}$ So, Lord Millet declined to use section 3 and stated that homosexuals were not recognised by the Rent Act at the time the legislation was enacted. This meant that the Court could not read the recognition of a same-sex partner's inheritance into the statute. ${ }^{77}$

\footnotetext{
${ }^{64}$ [2004] UKHL 30 para 33.

65 ibid 32 .

66 ibid 49.

67 [2003] 1 AC 837.

${ }^{68}$ Ghiadan v Godin-Mendoza [2004] UKHL 30, para 49.

${ }^{69}$ [2003] UKHL 21.

${ }^{70}$ Ghiadan, para 49.

71 ibid 49.

72 ibid 50 .

73 ibid 46.

${ }^{74}$ Ghiadan, para 99.

75 ibid 101.

76 ibid 101.

77 ibid 99.
} 
Lord Millet was also reluctant to issue a 'declaration of incompatibility' under section 4 of the HRA and reasoned that this would 'deliver a wound to Parliament's handiwork' ${ }^{78}$

Nevertheless, this case also clarified that the new judicial powers are subject to limitations. Firstly, judges cannot contradict the purpose of a statute. Secondly, matters relating to national security, morality and socio-economic factors must be deferred to Parliament. Thus, sensitive areas are reserved exclusively for the legislature. Moreover, in the case of International Transport Roth GmbH v Secretary of State for the Home Department, ${ }^{79}$ the High Court was of the opinion that, even though it was under a 'strong obligation' to 'turn the statutory language ... inside out', this case fell outside the periphery of section 3 . In this case it was difficult to make the statute Convention-compliant and so the judges could not 'turn the statutory language [...] 'inside out'. This was because they would be acting beyond the fundamental purpose of the statute as the statutory framework required considerable alteration. Therefore, they were left with no option but issue a 'declaration of incompatibility' pursuant to section 4 .

Ghaidan v Godin-Mendoza demonstrates that some judges are more willing to interpret the meaning of the statute by invoking section 3, rather than by referring the matter to the legislature under section $4 .^{80}$ This article asserts that the former option merely involves interpreting the statute by abiding by its fundamental purpose. On the other hand, political constitutionalists will argue that the judiciary is acting beyond its powers by delivering politically contentious decisions and subsequently interfering with the inner workings of the legislature. However, this argument carries little weight given that the judges usually apply the fundamental purpose of the statute as demonstrated by the case of Ghaidan and the other cases discussed above.

\subsection{Utilising the phrase 'intention of parliament'}

In order to interpret legislation under section 3, British judges use the phrase 'intention of Parliament' to reach decisions. Kavanagh elaborated on this further and stated that the phrase 'intention of Parliament' has several meanings. ${ }^{81}$ She stated that it may refer to Parliament's

\footnotetext{
${ }^{78}$ Anthony Bradley, The Sovereignty of Parliament: Form or Substance, in Jowell J and Oliver D (eds) The Changing Constitution, $7^{\text {th }}$ edition, OUP (2011) p. 65; Le Sueur \& et al [n 19] 762.

${ }^{79}$ [2002] EWCA Civ 158.

80 [2004] UKHL 30.

${ }^{81}$ Aileen Kavanagh, 'The Role of Parliamentary Intention in Adjudication under the Human Rights Act 1998' (2006) 26 Oxford Journal of Legal Studies 179.
} 
enacted intention which could easily be deduced by reading the statute. ${ }^{82}$ Alternatively, she stated that Parliament's presumed intentions can aid judges in fulfilling the role of ensuring compatibility with the ECHR. ${ }^{83}$ Young also explored some of the limitations that have been placed on courts when examining the intention of Parliament. ${ }^{84}$ For example, she stated that statutes should not be ambiguous, and 'reading in' words should not be appropriate when figuring out the 'intention of Parliament' at that time the statute was passed. ${ }^{85}$

Sales and Ekins are amongst the minority of commentators who argue that section 3 does not supersede the purpose of interpretation. ${ }^{86}$ They state that section 3 enables judges to act as interpreters to 'infer' that intention. ${ }^{87}$ According to them, judges are involved in 'making the law' on a case-by-case basis. However, they were not highly critical of this aspect because they contend that in some circumstances this is necessary. ${ }^{88}$ For example, because the legislation is not always clear and section 3 empowers courts to proceed beyond literal statutory interpretation. ${ }^{89}$ Of course, this approach does not clarify the law for the general public, which distorts the rule of law. Nevertheless, section 3 has, to an extent, transformed the role of the judiciary. Judges must interpret the 'intention of Parliament' at that time the legislation was passed to ensure that their judgment abides by the thrust of the legislation. From the case law discussed above, it is clear that judges invoke section 3 in accordance with the intention of Parliament'.

\section{The less frequent route used-Section 4}

As mentioned previously, section 4 of the HRA has empowered senior judges of higher courts to issue declarations of incompatibility. ${ }^{90}$ It is the courts' responsibility to inform Parliament that a provision of an Act is incompatible with the ECHR. ${ }^{91}$ However, such declarations do not affect the validity, continuing operation or enforcement of the provision. ${ }^{92}$ This illustrates that Parliament prefers to maintain its supremacy given that the legislative

\footnotetext{
82 ibid 179.

83 ibid 179.

${ }^{84}$ Alison L. Young, 'Judicial Sovereignty and Human Rights Act 1998' (2002) 61:1 Cambridge Law Journal 53.

85 ibid 53.

${ }^{86}$ Philip Sales and Richard Ekins, 'Rights-consistent interpretation and the Human Rights Act 1998' (2011) 127

Law Quarterly Review, 217.

87 ibid 217.

88 ibid.

89 ibid.

${ }^{90}$ Le Sueur \& et al [n 19] 766.

91 ibid 766.

92 HRA, s 4(2)(a).
} 
provision in question would be deemed invalid if, and only if, Parliament declared it so. ${ }^{93}$ Declarations of incompatibility do not even compel the government to amend the law. ${ }^{94}$ The best outcome of a declaration of incompatibility is that it delivers 'a wound to Parliament's handiwork that is likely to prove fatal' and thus it can be argued that this section slightly alters Dicey's idea of the supremacy of Parliament. ${ }^{95}$

Lord Steyn in Ghaidan v Godin Mendoza,${ }^{96}$ emphasised that section 3 should act as the 'prime remedy' and section 4 should always be used as a 'last resort' ${ }^{97}$ Likewise, Lord Millet was reluctant to invoke section 4 . When judges invoke section 4 , they are partially questioning the workings of the legislature. Baroness Hale provided a helpful explanation when she stated that 'declarations of incompatibility' play a positive role in warning the government and having an informed debate between the legislature and the judiciary about future legislation. ${ }^{98}$ She further stated that section 4 should be used to 'warn Government and Parliament, that, in our view, the United Kingdom is in breach of international obligations. It is then for them to decide what, if anything, to do about it' ${ }^{99}$

In the seminal case of $R$ (on the application of Nicklinson and another) $v$ Ministry of Justice, ${ }^{100}$ the Supreme Court considered whether section 2 of the Suicide Act 1961 was incompatible with Article 8 of the ECHR which ensures the right to respect for private and family life. ${ }^{101}$ Section 2 of the Suicide Act 1961 makes it a criminal offence to assist another person to commit suicide. The ultimate question was whether the court should issue a 'declaration of incompatibility' to the effect that section 2 was incompatible with Article $8 .{ }^{102}$

A majority of five justices held that the Supreme Court had the constitutional legitimacy to issue a 'declaration of incompatibility' in relation to the general prohibition of assisted suicide. The ban on assisted suicide was held to be incompatible with Article 8 of the ECHR. Nevertheless, there were apparent differences in views on the course of action to be adopted. Lords Sumption and Clarke believed that as the matter was political, the court could only issue

\footnotetext{
${ }^{93}$ Le Sueur \& et al [n 19] 766.

94 ibid 766.

95 Bradley [n 88] 65.

96 [2004] UKHL 30.

${ }^{97}$ Gavin Phillipson, 'Mis-reading section 3 of the Human Rights Act' (2003) 119 Law Quarterly Review 183

${ }^{98} R$ (Animal Defenders International) $v$ Secretary of State for Culture, Media and Sport [2008] UKHL 15, 53

99 ibid.

100 [2014] UKSC 38.

101 The European Convention on Human Rights, art. 8.

102 Le Sueur \& et al [n 19] 768.
} 
a 'declaration of incompatibility' if Parliament refused to consider this issue. ${ }^{103}$ However, Lords Reed and Hughes stated that this was a matter for Parliament alone due to its political ramifications. $^{104}$ Lord Neuberger acknowledged that under the UK's constitutional foundations, sensitive issues such as assisted suicide are very much within the contemplation of Parliament. ${ }^{105}$ However, Lord Neuberger also stated that less than five years ago, Parliament criminalised assisted suicide. ${ }^{106}$ Lord Neuberger further stated that the courts can still hold that the legislation infringes Convention rights despite the fact that it was changed by Parliament five years ago. ${ }^{107} \mathrm{He}$ stated something quite alarming- that sometimes unpopular decisions can be more easily taken by the judiciary, rather than the legislatures. ${ }^{108}$ Judges are not directly accountable to the electorate and on some occasions, judges have more freedom and leeway that enables them to take a detached view from the general public.

However, Lord Sumption held a different view and stated that politicians have the mandate to represent the community at large, and that this was not a matter of 'personal opinions' of judges. ${ }^{109}$ Rather, he stated that such opinions lack constitutional legitimacy, implying that judges are subordinate to the legislature and should not make politically contentious decisions. ${ }^{110}$ Lady Hale also stated that Parliament was the appropriate forum for such issues because of the UK's constitutional foundations, so there is more to be gained, than lost by issuing a 'declaration of incompatibility'. ${ }^{111}$

In addition, as mentioned earlier, section 4 has been applied more frequently in respect of terrorism acts, where the courts strike a balance between civil liberties and national security. For example, in the case of $A v$ Secretary of State for the Home Department, ${ }^{112}$ the House of Lords held that section 23 of the Anti-Terrorism, Crime and Security Act 2001 (which allows foreign nationals suspected of committing terrorist related offences to be detained indefinitely without trial) was contrary to Article 5of the ECHR. ${ }^{113}$ A 'declaration of incompatibility' was issued under section 4 of the HRA as section 23 of the 2001 Act was incompatible with Articles

\footnotetext{
103 ibid 768-9.

104 ibid 769.

${ }^{105} R$ (on the application of Nicklinson and another) $v$ Ministry of Justice [2014] UKSC 38, para 99.

106 ibid.

107 ibid 100 .

108 ibid 104.

109 ibid 230 .

110 ibid 230.

111 ibid 300.

112 [2004] UKHL 56.

113 Right to Liberty.
} 
5 and $14^{114}$ of the ECHR. Section 23 was disproportionate as it permitted the detention of suspected international terrorists which discriminated on the grounds of their nationality or immigration status. Lord Hoffman clarified that section 4 was used because matters relating to terrorism are politically contentious and therefore Parliament is the most appropriate forum. ${ }^{115}$

The issue in the case of $R$. (on the application of Steinfeld) $v$ Secretary of State for International Development, ${ }^{116}$ was whether sections 1 and 3 of the Civil Partnership Act of 2004 precluded different sex couples from entering into civil partnerships. These sections were declared incompatible with Articles 8 and 14 of the ECHR by the Supreme Court. ${ }^{117}$ The judges held that a 'declaration of incompatibility' should be issued in areas relating to sensitive policies. ${ }^{118}$ The Home Secretary suggested that the court should refrain from issuing a 'declaration of incompatibility' as her decision fell within the field of sensitive social policy. Despite these dissenting voices, the Supreme Court issued a 'declaration of incompatibility' because it considered that it had power under section 4 to do so and given the circumstances of this case, it would be wrong not to have recourse to that power.

Similarly, in $\operatorname{Re} Z$ (A Child) (Surrogate Father: Parental Order), ${ }^{119}$ it was held that sections 54(1) and 54 (2) of The Human Fertilisation and Embryology Act 2008 were incompatible with the rights of a father and his child under Articles 8 and 14 of the ECHR, as they prevented the father from obtaining a parental order on the sole ground of his status as a single person. ${ }^{120}$ The 'declaration of incompatibility' rested on Lord Neuberger's decision in $R$ (on the application of Nicklinson and another) $v$ Ministry of Justice ${ }^{121}$ where he explored the

\footnotetext{
114 The right to personal liberty under Article 5 and the enjoyment of the rights and freedoms set forth in this Convention shall be secured without discrimination on any ground such as sex, race, colour, language, religion, political or other opinion, national or social origin, association with a national minority, property, birth or other status under art. 14.

${ }^{115}$ A v Secretary of State of the Home Department [2004] UKHL 56, para 96.

116 [2018] UKSC 32.

117 Right to Respect for Private and Family Life and Prohibition from Discrimination, respectively.

${ }^{118}$ A v Secretary of State of the Home Department [2004] UKHL 56, para [61].

119 [2016] EWHC 1191 (fam).

120 The intended parents need to apply for a parental order when a child is born through surrogacy. A parental order will then transfer parentage from a surrogate mother to the intended parents-see Helen Savage, What is a Parental Order, Co-op Legal Services,

$<$ https://www.co-oplegalservices.co.uk/media-centre/articles-jan-march-2019/what-is-a-parentalorder/\#: :text=\%20A $\% 20$ Parental $\% 20$ Order $\% 20$ provides $\% 20$ for $\% 20 \mathrm{a} \% 20$ child, about $\% 20$ the $\% 20$ creation $\% 20$ of $\% 20$ the $\% 20$ embryo. \%20More $\% 20>$ accessed 28 December 2020.

121 [2014] UKSC 38.
} 
various ways by which the discriminatory effect of the present legislation could be cured and decided that it was constitutionally a matter for the legislature to determine. ${ }^{122}$

One can discern that the courts are less reluctant to invoke section 4 as compared to section 3 simply because judges do not want to criticise Parliament's handiwork. ${ }^{123}$ Indeed, the statistics corroborate this theory. A report by the Human Rights Joint Committee states that from 2015 onwards, the number of declarations of incompatibility issued by the UK courts under the HRA diminished significantly. ${ }^{124}$ It is alarming to note that the UK courts have only issued 29 declarations of incompatibility, 20 of which have been finalised. The report further highlights that during the 2010-2015 only three declarations of incompatibility were issued, however, one was appealed. ${ }^{125}$.

Courts and the Parliament should work in collaboration with one another to engage in an informed discussion about legislative matters, rather than resort to holding an egotistical war. Hickman states that the 'dialogue approach envisages courts proposing arguments of principle to the political branches and in return this way, the HRA provides an effective synthesis of parliamentary democracy and human rights by forging a partnership between the legislature, executive and judiciary'. ${ }^{126} \mathrm{Nicol}^{127}$ and Young ${ }^{128}$ state that Parliament should consult courts in sensitive policy matters.

\section{The upcoming review of the HRA}

Since 2010, the Conservative Party has considered replacing the HRA with the new British Bill of Rights. ${ }^{129}$ The Conservatives state that section 3 of the HRA undermines the principle of parliamentary sovereignty as it allows the British courts to interpret domestic legislation 'as far as it is possible to do so' in light of the ECHR. ${ }^{130}$ The Conservatives propose

\footnotetext{
122 [2016] EWHC 1191 (fam) para 19 and 38.

${ }^{123}$ For recent cases where the courts decided not to invoke section 4, please see the following: Northern Ireland Human Rights Commission's Application for Judicial Review, Re [2018] UKSC 27; R (on the application of Conway) v Secretary of State for Justice [2017] EWHC 2447 (Admin).

${ }^{124}$ Human Rights Joint Committee (2015), Human Rights Judgments, (HL Paper 130, HC 1088).

125 ibid.

126 Tom Hickman, Public Law after the Human Rights Act (Oxford, Oxford Hart Publishing 2010) 60.

${ }^{127}$ Danny Nicol, Law and Politics after the Human Rights Act (2006) Public Law 722.

128 Alison L. Young, 'Is dialogue working under the Human Rights Act 1998' (2011) Public Law 773.

${ }^{129}$ David Mead, 'What Will Replace the Human Rights Act'(British Politics and Policy blog, LSE, 2 October 2014) $<$ https://blogs.lse.ac.uk/politicsandpolicy/what-will-replace-the-human-rights-act/> accessed 15 November 2020.

${ }^{130}$ The Conservatives, 'Protecting Human Rights in the UK: The Conservatives Proposals for Changing Britain's Human Rights' (Conservative Party, October 2014)

$<$ http://news.bbc.co.uk/1/shared/bsp/hi/pdfs/03 $10 \quad 14$ humanrights.pdf $>$ accessed 15 November 2020.
} 
that judicial activism would be decreased as a result of these changes. ${ }^{131}$ This makes little sense because most of the case law in this area illustrates that judges abide by the fundamental purpose of the legislation when interpreting it in line with the ECHR.

In December 2020, the Conservative Party instituted an independent review of the HRA to assess if any changes were required. ${ }^{132}$ The review focuses on the relationship between domestic courts and the ECtHR, and secondly, on the impact that the HRA has on the relationship between the executive, the legislature and the judiciary. ${ }^{133}$ To this end, the review examines whether a proper balance is struck between the courts, the executive and the legislature and whether domestic courts are adjudicating on areas of policy. ${ }^{134}$ The panel will also consider whether a reform is needed. Given the aims of this review, it is clear that the Conservative Party believes that section 3 grants too much leeway to the judiciary, ${ }^{135}$ despite the abundance of case law which suggests otherwise.

\section{Conclusion}

The purpose of this article was to demonstrate the extent to which the HRA has empowered the judiciary to adopt a more activist approach. The adoption of the HRA has been warmly welcomed by legal constitutionalists. Case law reviewed in this article demonstrates that judges abide by the fundamental purpose of the statute when interpreting its provisions. However, Diceyans and political constitutionalists would never have desired such a change because, they argue that judges look beyond the ordinary meaning of the statute to make it Convention-compliant. However, case-law discussed in this article indicates that this is not the case.

It is clear that section 3 has had a more profound impact than section 4 of the HRA because the former gives rise to a new interpretative duty that enables the judiciary to interpret domestic legislation in a way that is compatible with the ECHR. Whereas under section 4, courts can simply alert Parliament of the alleged defects in the statute. This means that

\footnotetext{
${ }^{131}$ Tim Shipman, 'Human Rights Law to be Axed' The Sunday Times (8 November 2015). $<$ https://www.thetimes.co.uk/article/human-rights-law-to-be-axed-nxr6nx5929f> accessed 15 November 2020

${ }_{132}$ Ministry of Justice [n 24].

133 ibid.

134 ibid.

135 ibid.
} 
Parliament remains responsible for amending domestic legislation to make it Conventioncompliant.

The emergence of the HRA has somewhat reinstated the tension between the rule of law and parliamentary sovereignty. Parliamentary sovereignty has not been diluted because judges appear to be interpreting legislation in line with its fundamental purpose. It can also be argued that Parliament has given courts the mandate to interpret legislation in light of the ECHR. If Parliament wills, it can remove this entitlement which seems to be an issue in the latest review of the HRA. Thus, since the implementation of the HRA, parliamentary sovereignty has not been eliminated. The HRA has initiated a debate about bi-polar sovereignty and its impact on the UK's constitutional arrangements. The bi-polar sovereignty arrangement between the Parliament and the judiciary is healthy for democracy, however, case-law discussed in this article demonstrates that judges interpret legislation in line with its fundamental purpose, meaning that Parliament has retained its sovereignty. 